\title{
Accounting Information System Courses: Developing a Hybrid Syllabus in the Era of Digitization
}

Faten F. Kharbat. College of Engineering, Al Ain University. Abu Dhabi. faten.kharbat@aau.ac.ae

Riham Muqattash. College of Business, Al Ain University. Abu Dhabi.riham.muqattash@aau.ac.ae

\begin{abstract}
Technology is becoming a major pillar in many professions. It plays a critical role in developing and enhancing the quality and accuracy of tasks. Because the formal education system is the first place where future employees are educated, it is very important to ensure that educational institutions offer continuously updated technology-related courses that cover a wide range of new and emerging topics. This research has two objectives. First, it explores the validity of the claim that AIS education is of low quality in the Middle East, as stated in some studies. This is conducted through highlighting the status quo for AIS courses in Arab countries within the Middle East by focusing on a representative case study. This part of the work was conducted through a thorough exploration of the universities' websites and by distributing and analyzing a survey for faculty members in a number of universities. Second, the research performs a deep analysis to develop new, up-to-date, aligned objectives, contents, resources, and assignments in order to create a new, comprehensive syllabus in the higher-education sector that will serve stakeholders from universities to accounting communities. The output of this research identified suitable learning objectives based on current literature and faculty responses. This was followed by designing new course content and assessment tools that are aligned with learner- and competency-centered approaches.
\end{abstract}

Keywords: Learner-centered, competency-centered, accounting information systems, digital accounting, syllabus. 


\section{INTRODUCTION}

The digital transformation has resulted in significant changes to organizational structures and processes (Vial, 2019). From an accounting perspective, information technology "strengthens the construction of financial accounting systems" (Zhu \& Li, 2019) in organizations. This has led to several changes to the "value creation model and its related financial tenets" (Quinn \& Strauss, 2017). It is said that accounting is the "language" of business; if this maxim is true, then an accounting information system (AIS) is the vehicle for that language (Romney \& Steinbart, 2018). Many researchers and practitioners have noted the extensive changes taking place in the field of AIS (Damasiotis et al., 2015; Krahel \& Vasarhelyi, 2014) as new types of information system (IS) technologies have emerged and evolved. This evolution may result in changing the way accountants work (Damasiotis et al., 2015).

Because the formal education system is the first place where students are educated, it is crucial to update technology-related courses to ensure coverage of new topics and thus prepare graduates for future workplaces and ensure their competency within those workplaces (Qasim \& Kharbat, 2020). AIS is "a crossdiscipline subject, often taught by Computing and Accounting disciplines" (Tran \& Anvari, 2013). It has been defined as "a computerized system that is used for performing accounting operations using IT resources" (Damasiotis et al., 2015). According to Monk and Wagner (2012), the accounting profession was the first to use IS applications by automating accounting data operations (e.g., retrieving, storing, and calculations) via the use of simple spreadsheet programs such as Microsoft Excel. The importance of accounting graduates having a deep knowledge of AIS rises from current concerns about the absence of this knowledge in accounting courses. These concerns range from "poor decisions, inefficiencies and weak communications" to a "lack of strategic and goal congruence" (Quinn \& Strauss, 2017). Lois et al. (2017) and Caglio (2003) highlighted the concept of the "hybridization" of the accounting practice phenomenon; this indicates that accountants are increasingly performing nonaccounting tasks, and non-accountants are required to execute accounting-related tasks. Increasingly, employers are looking for professional accountants who "possess technical knowledge and skills" and who can cope with complex business models and transactions (Qasim \& Kharbat, 2020; Rufino et al., 2017). 
This new reality means that accountants must be knowledgeable in various information technology trends associated with accounting tasks. It also supports changes that have been made to accounting courses to include contemporary skills such as adding new technologies, as well as strengthening fundamental skills such as problem-solving. There is a gap between what students learn at university and what the labor market needs (Paterson \& Wilson, 2018). Although 90\% percent of college graduates are well prepared to meet labor market needs (Book, 2014), employers do not feel that graduates from accounting major have the required skills (Qasim \& Kharbat, 2020; Rufino et al., 2017). This makes it important to link formal education with needed skills in the workplace.

AIS education in developing countries has also been a focal point for some time (Al-Eqab et al., 2015; Maali \& Al-Attar, 2020; Srdar, 2017). Chapman \& Miric (2009) investigated the quality of teaching in the Middle East. They suggested that education in countries within the Middle East and North Africa (MENA) "is lagging compared to many other parts of the world." In their study, they aimed to set an alarm about the fact that "low quality of education" is a challenge facing decision-makers in the education industry and government leaders. This alarm was followed by several other alarms. For example, Akkary (2014) stated that MENA universities "fall short of preparing [students] for the demands of a postmodern technological world". It is known that quality of education, schools, and higher education are a very wide concept (Bowe, 2015) that is beyond the research focus. However, performance indicators are one of the known methods that can be used to evaluate and test separated areas in the general one. One of the areas related to quality of education in this research is the indicators associated with using information technology (Azma, 2011; Cabaleiro-Cerviño \& Vera, 2020). Different models of using technological tools were suggested in the literature, such as blogs and webpages, to promote quality of education and indorse "improvements in learning" (Cabaleiro-Cerviño \& Vera, 2020).

Therefore, this research has two objectives. First, highlight the status quo for AIS courses in Arab countries within the Middle East in order to explore the validity of the claim that AIS education is of low quality in the Middle East, as stated in some studies. Since the quality of education is a wide concept, the aim of the research is limited to evaluate the data collected from the webpages associated to AIS by focusing on a representative case study. Second, the research performs a 
deep analysis to develop new, up-to-date, aligned objectives, contents, resources, and assignments in order to create a new, comprehensive syllabus in the highereducation sector that will serve stakeholders from universities to accounting communities.

To achieve these objectives, this paper is organized as follows: Section 2 outlines the background of the work, Section 3 outlines the research methodology and the needed resources, and Section 4 comprises the results and the design if the newly created syllabus. The conclusion and implications are presented in Section 5.

\section{BACKGROUND}

\subsection{Syllabus Design}

Designing a syllabus is a key factor to implement the objectives and goals of any educational program; however, the importance of this tool is often ignored (Ishiyama et al., 2015). A syllabus is a powerful motivational tool that maps out the learning path and fosters positive student engagement throughout a course (Harrington \& Thomas, 2018). Prior research has highlighted the importance of a syllabus as a communication, planning, and recording tool, as well as a cognitive map and learning aid (Harrington \& Thomas, 2018; Parkes \& Harris, 2002; Richmond, 2016).

Different approaches can be used to design a syllabus (Murphy, 2018), including task-centered (Ellis, 2003; Maali \& Al-Attar, 2020), learner-centered (Robb, 2012), competencies (skills)-centered (Mamaghani \& Zolghadri, 2018), and content-centered (Stoller, 2004). Each approach has its own strengths and preferences based on the environment in which it will be used and the course material it will cover. To benefit from the different strengths of each, this study utilizes two different approaches: learner-centered and competency-centered.

A learner-centered syllabus is "an attempt to create community, a sharing of power and control over what is learned and how it is learned as well as a focus on assessment and evaluation tied directly to learning outcomes" (Cullen \& Harris, 2009). The research community has built up several cases to prove that learnercentered syllabi contribute to both teachers and students. Richmond (2016) stated that using this type of syllabus results in better engagement with students, stronger bonding with tutors, and the ability to retain more course information. The instructor needs to create the syllabus by using three main elements: community, 
power and control, and evaluation and assessment (Cullen \& Harris, 2009). In terms of community, the instructor must make use of learning rationale along with community collaboration, which means giving students the reasoning behind the assignments given to them as a way to encourage them to learn from each other through group work (Weimer, 2002). Power and control refer to sharing the building of the syllabus with the students on the first day of classes by choosing the assignment, its due date, and its marking weight. The learner-centered approach encourages involving students in creating rules of behavior for the classroom (DiClementi \& Handelsman, 2005).

Gervais (2016) defined competency-centered education as "an outcome-based approach" that integrates assessment efforts and instructional delivery to evaluate "mastery of learning by students through their demonstration of the knowledge, attitudes, values, skills, and behaviors required for the degree sought." He argues that educational programs must include innovative approaches through merging the concept of applying theory to practice to measure student-learning outcomes. In this approach, technology typically combines knowledge, skills, and values (AICPA, 2018; Rufino et al., 2017), which are then combined into a competency. However, aspects from the learner-based syllabus are adapted to ensure the students' engagement, satisfaction, and retention (Jones et al., 2016). Each objective is indicated as knowledge (K), skills (S), and values (V).

Another well-known approach to developing syllabi is the competency-centered approach, also called problem-based learning, mastery-based learning, outcomebased learning, or performance-based learning (Gervais, 2016). In this approach, the competencies needed for the course and their development are outlined in the syllabus. This approach is used when "qualification specifies expectations in terms of outcomes, or what an individual can accomplish, rather than in terms of an individual's knowledge or capabilities" (Boritz \& Carnaghan, 2003). It is believed that competency-centered education helps teachers assess the educational intervention needed for students during the learning process (Le et al., 2014), since it provides a clear idea of the skills and knowledge students must acquire in a course, and is considered an important tool to "improve teaching and student learning" (Johnstone \& Soares, 2014). Its use represents a shift from content- to skills-based learning approaches (Daigle et al., 2007). 
It is believed that the use of both competency-centered and learner-centered syllabi helps students become more engaged in course material, increases their interest in learning, and, consequently, produces high-quality learning outcomes (Bakke et al., 2007).

\subsection{Course Concepts and Content}

Al-Eqab et al. (2014) investigated whether the AIS course content in Jordanian universities satisfies IFAC requirements. The study results revealed poor compliance of AIS course content with IFAC requirements. Following these results, other research by Al-Eqab et al. (2015) was conducted to examine the consistency between the AIS curriculum in Jordanian universities and IFAC requirements. The researchers provided a curriculum model and suggested learning outcomes for the AIS courses. El Kadiri et al. (2016) built their research on the McKinsey report on IT-enabled business trends for the next decade (Bughin et al., 2013). They defined four significant challenges facing IS in the current era: (1) data value chain management, which comprises information analysis, data mining, data integration, sharing, and security; (2) context awareness, which is related to scalability issues and integration capabilities between business processes; (3) interaction and visualization, which refers to interaction with technology; and (4) human learning and continuous education, which focuses on the development of professional competencies related to the new technologies. However, Cearley et al. (2017) highlighted the latest top-10 strategic technology trends. Intelligent trends comprise foundations of artificial intelligence, intelligent applications, analytics, and intelligent thinking. Digital trends comprise digital twins, cloud edge computing, conventional platforms, and immersive experiences. Mesh trends comprise blockchain, event-driven models, and continuous adaptive risk and trust.

Bendovschi (2015) divided AIS into three main types or categories: (1) onpremises accounting, which is the software purchased and installed for an organization to cover its regular accounting processes using the organization's infrastructure; (2) hosted solutions, in which the organization has access to its accounting software via a third party using remote access features, thereby reducing costs and maintaining value; and (3) cloud computing, in which data are managed through virtual platforms, allowing "multi-tenancy of services" to utilize the infrastructure as much as possible. 
Paterson and Wilson (2018) reviewed the main disciplines, organizational effects, control, and future directions of AIS that are evolving in the current era. Romney and Steinbart (2018) highlighted the increase in a company's control failures due to threats from AIS, noting that one of the basic objectives of AIS is to control the organization's business. They stressed the importance of an organization's accountant's having a thorough knowledge of IT risks by using different control frameworks such as COBIT and ERM. (COBIT is a framework for IT governance and management. ERM was designed to support management to manage risks and opportunities.)

\subsection{The AIS Syllabus}

Few studies have examined adjustments made to AIS syllabi in recent years. Tempone et al. (2012) clarified the demand for making a review of the curriculum of AIS in order to turn out qualified graduates. In addition, Loo and Bots (2018) assessed AIS course development, texture, and content in a Dutch university from 2010-2015 through examining the three parties involved in these courses: students, faculty members, and program management. Al-Eqab et al. (2015) investigated the consistency between Jordanian universities teaching AIS curricula. Learning outcomes and International Federation of Accountants (IFAC) requirements (International Education Practice Statement 2 and International Education Standards 2) results indicated inconsistencies between the AIS curriculum in Jordanian universities and IFAC standards. This finding underlines the need for policymakers' attention to this issue. Quinn and Strauss (2017) analyzed the impact of ceaseless technological advances on the role played by the accounting profession. They noted the evolution of AIS in terms of the fact that constant professional skill development is crucial for accounting professionals, and that it helps accounting professors deliver and assess their courses to meet this need. Wessels (2010) developed a syllabus based on a competency-based approach by linking learning outcomes with needed competences; he noted that students must fully understand the syllabi so that they can apply their knowledge in critical thinking and solving problems, and so that they can encourage students to understand and engage with material, not simply memorize it.

As noted, the accounting profession is constantly evolving. The need to link IT with accounting has been demonstrated by, for example, Qian et al. (2012). Their study examines how businesses expected their accountants to have an 
understanding of IT knowledge, including frameworks such as COSO (Committee of Sponsoring Organizations of the Treadway Commission), ERM (enterprise risk management), COBIT (Control Objectives for Information and Related Technologies), and ITIL (Information Technology Infrastructure Library). Professional accountants must have a summarized overview of these approaches, and then this must be incorporated into AIS courses. On the other hand, Islam et al. (2017) and Belfo and Trigo (2013) outlined in their study the importance of including enterprise resource planning (ERP) in AIS and encouraged future research to find new mechanisms that have an impact on accounting functions. They also emphasized the importance of including ERP topics in AIS courses, and how it affects accounting functions in an organization. Romney and Steinbart (2018) stressed the importance of accounting graduates gaining a better understanding of how IT systems work, as well as the importance of ERP in AIS courses.

Apostolou et al. (2014) performed a literature review of AIS topics and encouraged researchers to explore "what must be improved in the AIS course." They suggested that best practices should be outlined in the AIS curriculum. They also advocated for future research that will examine the AIS course structure, including textbooks, course material, and course content.

There has also been an effort to increase accounting graduates' understanding of a code of ethics. McPhail (2001) stressed the importance of adding teaching on ethics to accounting courses as a way to enhance professionalism. Ten years later, Liu et al. (2012) explored deficiencies in accounting graduates' ethical reasoning skills and their ability to solve ethical dilemmas. They also examined how accounting educators and universities must improve the moral reasoning of accounting students through a greater emphasis on ethical issues in accounting courses. IFAC's handbook (2010) highlights the importance of students understanding that ethics and values are an intrinsic part of everything that professional accountants do, and of their role in providing trust and confidence in the market. Limijaya (2018) recommended including an ethics course in the accounting curriculum as a stand-alone course, if possible; otherwise, it should be incorporated into accounting courses and covered in the syllabi. An Al-Eqab et al. (2014) investigation revealed that $92.5 \%$ of Jordanian universities use Romney and Steinbart's textbook in their AIS courses. 
Moreover, given the importance of data to business success, IFAC stated that the "accounting profession needs a better understanding of the [business accountant's role] in data science and analytics" (Gould, 2019). In response to the rising importance of data and technology, the Institute of Management Accountants (IMA), for example, has released an enhanced Management Accounting Competency Framework for Professionals in the Digital Age. In addition, IFAC (2007) "identified various roles for accountants within an IS, such as the accountant as user of an IS (e.g., financial manager and controller, tax practitioner, information analyst, etc.)."

The Association to Advance Collegiate Schools of Business (AACSB) (2018) Standard A5 (formerly A7, in AACSB 2013) requires that both faculty and students in accounting majors should develop learning experiences related "to the integration of information technology in accounting and business." These are needed to "adapt to emerging technologies as well as the mastery of current technology."

The standard clearly states that data creation, manipulation/management, security, and storage are part of the components that should be added to the curriculum, along with data analytics and "developing information technology agility," to enable students and faculty to adapt to the current and future era. Notably, however, the AACSB does not consider creating and formatting files or developing a presentation as a required skill; rather, it assumes that those skills have been acquired elsewhere. The required skills include, but are not limited to, statistical techniques, data mining, data management, modelling, analysis, learning systems, and visualization techniques.

\subsection{Information Technology Indicators in Quality of Education}

Indicators for quality of education have been the focus of many researches since a long time (Agrawal \& Mittal, 2018; Cabrol \& Severin, 2010). Information technology is considered to be a facilitator to improve education and its quality, and thus, it covers more than dimension category (Bowe, 2015) to be assessed and evaluated (Azma, 2011; Law et al., 2016). Noor-Ul-Amin (2013) argued that the accessibility of information is considered as one of the dimensions to improve quality of education using the information technologies tools and techniques. He expanded the information technology affect to include enhancement of "delivery of education and enable wider access" to stakeholders (Noor-Ul-Amin, 2013). 
Law et al. (2016) and Bowe (2015) focused on the indicators addressing the dimension of using information technology in "ensure[ing] inclusive and equitable quality education" (Law et al., 2016) and "measuring equity in education opportunities" (Bowe, 2015). Where Azma (2011) listed some indicators about the learning environment to support virtual classes, paperless communications, and automated systems. Other researchers highlighted other areas such as monitor of education (Law et al., 2016), implementation indicators (Agrawal \& Mittal, 2018), and competences and professional abilities (Bezpalko et al., 2016). Skordoulis et al. (2015) proposed a set of characteristics that can be used to measure quality of education such as reputation, offered curriculum, services and additional services. The reputation of an educational institution was measured based on different items including the websites and the accessibility of the information.

Since the area of information technology in quality of education is wide and following Skordoulis et al. (2015), this research will only focus on the first step for students, parents, teachers, or other stakeholders, which is the AIS related website. It can be the school/ college webpage, the study plan for a major, the AIS major webpage, the availability of the syllabus online, or any related page for the course in any other way.

\subsection{Arab Countries in the Middle East}

The region between Asia and Europe is called the Middle East. This region consists of 17 countries, of which 13 are Arab countries. In this research, the focus is limited to the Arab region of the Middle East as an extended case study for different previous studies (Maali \& Al-Attar, 2020; Srdar, 2017), as these countries share very similar educational systems. Some differences do exist between these countries, however, as they vary in population size, growth rate, and general income. The challenges in the Arab MENA region have become greater over time, particularly in education. Although many researchers have tackled issues in education in this area in order to evaluate, assess, or recommend solutions, the existing research still comes up short. With a total population of 258,060,487 million in the Arab counties within MENA and a maximum projected growth percent rate of 4.6 percent (Data.worldbank.org., 2019), the challenges continue to grow. This rate of population growth contributes to the challenges that Arab countries are having in terms of business, education, and 
development. This study aims to remedy a very small part of these challenges by focusing on the AIS course, as it is the integrating factor between accounting and IS.

\section{RESEARCH METHODOLOGY}

The development of course objectives, content, resources, and assessment tools is a project in and of itself. A descriptive analysis is conducted to explore the status quo for AIS course in the region. The analysis is based on a web-based search into the universities' websites to extract the needed information. To understand the status quo for AIS courses in the targeted region, courses at both public and private universities in the Arab Countries in the Middle East were examined. For public universities, a search in UniRank (2019) was conducted between April and August 2019. UniRank is one of the leading international higher-education directories for approximately 200 countries. The search uncovered 176 public universities in the 13 selected countries. The website for each university was visited between April 2019 and June 2019. For private universities, the search uncovered 214 universities. The website for each university was visited between August 2019 and November 2019. The number of websites that were universities were 19 and 37, public and private universities respectively; the URL was either broken or the website's services were down.

As a way to strengthen the information found on the universities' websites, a short survey was developed to collect faculty responses about the AIS courses offered at their universities (if applicable). In order to send the survey to as many faculty members as possible, a simple tool was developed using Python ${ }^{\mathrm{TM}} 3.7 .3$ to collect faculty email addresses from the website. The tool collected approximately 1,300 emails from the 13 countries, of which 319 emails were found to be invalid. The survey was then sent to approximately 981 email addresses. The survey questions were provided in Appendix A.

The next part is conducted following Scheckel's procedure (2016), which is based on Fink (2013), to scientifically build up a course syllabus. It begins with the students' backgrounds and experiences, and the program level. This is the predesign phase, which directs the course design and any related material. The iterative procedure (as shown in Figure 1) discussed in Scheckel (2016) continues by (1) defining learning objectives, competencies, and outcomes, then (2) decide the course concepts and contents, (3) select the suitable material and resources, 
and (4) design the assessment methods and feedback. Hence, the next section begins by highlighting the status quo, and then moves to using this data to build the sections of the new syllabus.

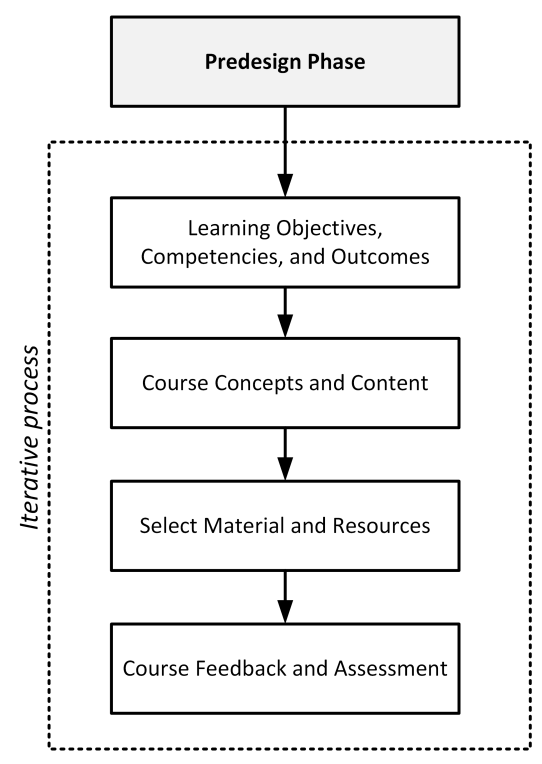

Figure 1. Iterative course design process. Adapted from Scheckel (2016)

The suggested learning objectives were discussed in a focus panel comprising the development team and three other faculty members in the quality assurance, accounting, and computer science disciplines. The aim of the focus group was to discuss the learning objectives to ensure their alignment to the course, as well as their learner- and competencies-based style. In addition, to comply with the international and national standards, several accreditation bodies, such as AACSB, AICPA, IFAC, UAE Program Accreditation Commission, and Jordan Legislations of higher education were referenced to suggest the assessment tools, course structure, and design.

\section{RESULTS AND DISCUSSION}

\subsection{AIS Courses: The Status Quo in Arab Countries in the Middle East}

The results showed that 110 public universities and 99 private universities offer an accounting major. It is worth noting that from the 209 universities offering accounting, only 79 public and 60 private universities provided information about the course name and a description of the course content on their website. 
However, most did not outline any other information about the course, such as the number of credit hours, assigned practical hours, the year in which the courses were offered, or any required prerequisites. Of the public universities, only 30 public and 25 private universities provided full information about the accounting courses they provide.

The universities accessibility and websites evidence will affect the quality of education from some perceptive (Kesswani \& Kumar, 2016). University data shared on their websites reflect their quality of education in some way by encountering existence planed courses, the programs and academic majors, the academic work in different majors, and giving a clear picture of the university activities (Saichaie \& Morphew, 2014). Online teaching is targeted to become standard by 2025 (Palvia et al., 2018), and this will require universities to maintain their online materials starting from the majors' plan and syllabi. While the domain of this study is to develop an intelligent hybrid syllabus for the accounting information course, addressing the requirement for technological profound logical abilities is essential to snapshoot the quality of education.

The survey (in Appendix 1) discussed in the methodology section was sent to approximately 981 email addresses, and the results obtained from the survey were then analyzed (see Table 1). The response rate was $12 \%$, and 116 respondents provided answers. The achieved response percentage is acceptable, as this was an external survey. To validate the internal consistency, the Cronbach's alpha was calculated and was found to be .706; this is considered to be acceptable, since it is $>0.70$.

\begin{tabular}{|l|l|l|l|}
\hline Type of university & $\%$ & $\begin{array}{l}\text { Does the university offer AIS } \\
\text { courses? }\end{array}$ & $\%$ \\
\hline Private & $65 \%$ & No & $18 \%$ \\
\hline $\begin{array}{l}\text { Government } \\
\text { (public) }\end{array}$ & $21 \%$ & Yes & $51 \%$ \\
\hline Semi-public & $14 \%$ & AIS is a major & $31 \%$ \\
\hline
\end{tabular}




\begin{tabular}{|l|l|}
\hline Year of offering & \%* \\
\hline Year 1 & $13 \%$ \\
\hline Year 2 & $27 \%$ \\
\hline Year 3 & $56 \%$ \\
\hline Year 4 & $63 \%$ \\
\hline
\end{tabular}
* The percentage is only for the universities that offer AIS course.

Table 1. Results from a survey distributed to faculty in Arab Middle East universities

Table 1 data show that $65 \%$ of the participants work at private universities in eight Arab Middle East countries. The responses show that approximately $18 \%$ of participants do not have AIS courses at their universities, either because they specialize in medical or technology majors, or because they offer other IT- or business-related courses. Approximately $56 \%$ of the participants' universities offer AIS courses in the third year of study, and $63 \%$ in the fourth year.

The following summarization points can be made from examining the data from the websites and the supported survey results:

- The majority of universities offered two AIS courses for accounting. One was an introduction to information technology, and the other was a traditional AIS course. Some universities in Iraq and Lebanon offered three to four courses: Accounting Applications Using Excel, Accounting Applications Using SPSS, AIS I, and AIS II. Most universities offered the AIS course in the fourth year, which indicates that this is an advanced course to implement whatever accounting knowledge was acquired in the previous years. Notably, if a university offered more than one related course, one of them could be taken during the first part of the third year as a foundation for students. One note is that AIS is an active course offered in Middle East universities. This course tends to be an advanced course where the student is already familiar with the accounting concepts and terminology.

- The information available on the universities' websites is not complete; however, from the description of the available courses it can be concluded that these courses mainly focus on introducing the concept of databases to accounting students. Some universities offer detailed topic information, including on how to design a database and how to manage it. Although the 
use and creation of databases is still an active subject in computer science, accounting students are not usually involved in such technicalities, especially because they cannot usually master this highly technical skill in such a short period of time.

- The main topics covered in AIS courses at the universities were primarily an introduction to IT, the theory behind AIS, computerized transaction processing systems, an understanding of databases, and, in some cases, how to use SPSS for accounting. The descriptions found on the universities' websites highlight a lack of focus on more modern/recent technologies. Not only are blockchains and cloud computing not included, but some older technologies such as real time information (RTI) (Rezaee et al., 2000), ERP (Scheer \& Habermann, 2000), and eXtensible Business Reporting Language (XBRL) (Arndt et al., 2006) are also absent.

\subsection{Learning Objectives, Competencies, and Outcomes}

In this study, the development team consisted of two faculty members: an associate professor of data mining and knowledge discovery, and an assistant professor of accounting and auditing. Based on various strategies outlined in the literature regarding course design, the team began with a status quo analysis to identify the status of the AIS syllabi used in the Arab MENA region.

After identifying the status of the course given to students, the program level, further discussion among the development team resulted in the creation of a list of learning objectives that students should achieve by the end of the course. Based on the regulations in Arab Universities, for example, the UAE (CAA, 2019, p. 98) and Jordan (MoHE, 2018), and as per the majority of syllabi collected from universities, the resulting course is planned to be offered face-to-face for three hours weekly for 16 weeks, as per common regulations in the Arab Middle East countries. However, the suggested syllabus may be modified to suit other educational systems.

The development team acknowledged that the course must combine both competency and learner-based approaches. The development team developed a set of learning objectives following an example set by Sharifi et al. (2009), who developed a competencies-based accounting communication course for graduates; and an operational guideline set by Gervais (2016). 
Today's accounting graduates must have a very different education from that of their predecessors, especially in terms of acquiring necessary skills in using technology effectively and efficiently (Handoyo \& Anas, 2019). To identify needed competencies for accounting professions, the AICPA, the leading professional organization for practicing certified public accountants, identified in several published reports, "a set of skills-based competencies students entering the accounting profession need, regardless of their chosen career path" (AICPA, 2018). In addition, Rufino et al. (2017) "described the profile of the professional accountants as to the type of business operation and forms of business organization they are engaged with."

Accordingly, a set of eight learning objectives were developed to cover these components and to fulfill the expectations from this course. Based on Biggs's (1989) model (see Figure 2), the learning process is an interacting system of four sets of variables: the learning environment, students' characteristics, students' approaches to learning, and learning outcomes. The course learning outcomes are considered the main element with which to maintain a continuous quality assurance process, provide the instructor with insights about what the course intended to offer, and guide the matching assessment tools to measures these learning outcomes (Aleqab et al., 2015).

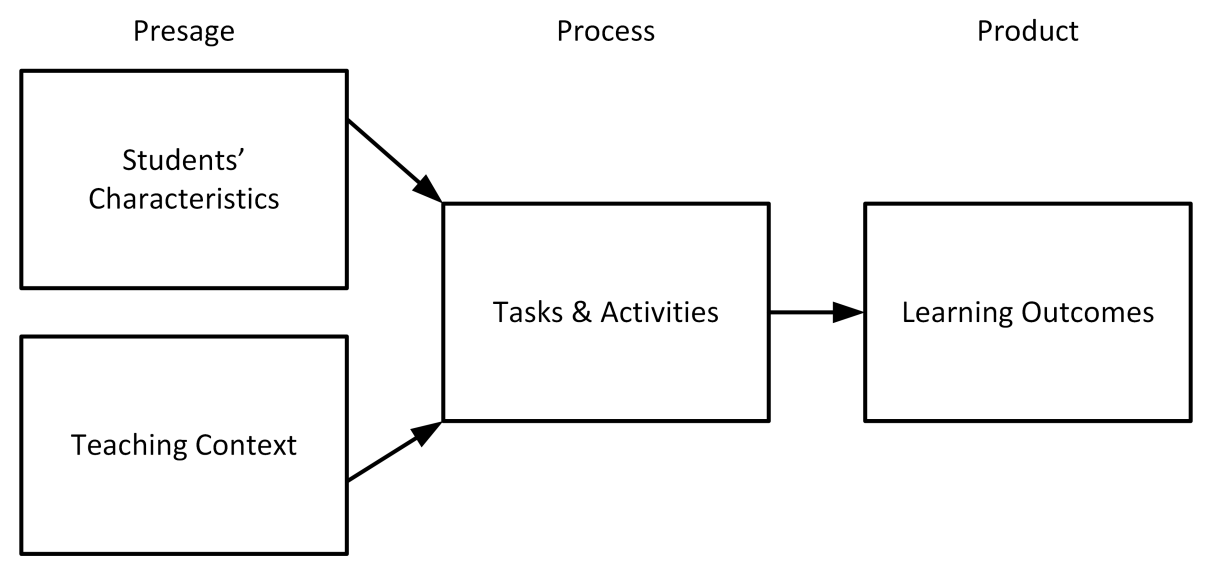

Figure 2. Presage-process-product model. Source: Adapted from Biggs (1989)

The discussion in the focus panel was fruitful and produced some unexpected discussion points about Bloom's taxonomy (Krathwohl \& Anderson, 2009) and best practices to develop learning objectives for a course on the one hand, and for 
a program, on the other hand, and the increasing need to focus on ethical issues, as the Guragai et al. (2017) study revealed that AIS and ethics are at a crucial crossroads. As well, IFAC (2010) issued the International Education Standard 4: "Professional Values, Ethics and Attitudes" which accountant should acquire during the education program leading to a qualification in evaluation of computerbased systems (align with AIS and IT modules) including (i) Legal and ethical requirements, (ii) Auditing standards relevant to information technology (IT), (iii) Computer control guidelines. At the end of the discussion, a set of six learning objectives was created that, at the end of the course, every student should be able to achieve, as outlined in Table 2.

\begin{tabular}{|c|c|c|c|c|c|}
\hline$\#$ & Student Learning Objectives & $\mathbf{K}$ & $\mathbf{S}$ & $\mathbf{V}$ & Comment \\
\hline 1. & $\begin{array}{l}\text { Perform the steps in the decision- } \\
\text { making process using } \\
\text { accounting-related technologies } \\
\text { (e.g., Excel, SAP). }\end{array}$ & 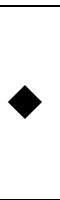 & $\diamond$ & & $\begin{array}{l}S \text { : Information literacy } \\
\text { skills and critical } \\
\text { thinking and } \\
\text { communication skills }\end{array}$ \\
\hline 2. & $\begin{array}{l}\text { Explain the business process } \\
\text { risks and internal controls using } \\
\text { data analytics and data mining. }\end{array}$ & 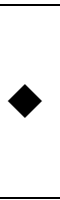 & $\diamond$ & & $\begin{array}{l}S: \text { Information literacy } \\
\text { skills and data } \\
\text { analytics skills and } \\
\text { critical thinking }\end{array}$ \\
\hline 3. & $\begin{array}{l}\text { Generate document flowcharts } \\
\text { and dataflow diagrams for use in } \\
\text { the interactive features of Web } \\
2.0 \text {. }\end{array}$ & 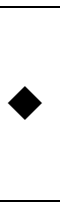 & 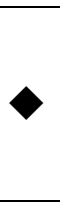 & & $\begin{array}{l}S: \text { Information literacy } \\
\text { skills and } \\
\text { communication skills }\end{array}$ \\
\hline 4. & $\begin{array}{l}\text { Differentiate between control } \\
\text { frameworks (COBIT, COSO, and } \\
\text { ERM) }\end{array}$ & & & & \\
\hline 5 . & $\begin{array}{l}\text { Illustrate forensic accounting- } \\
\text { facing business financial records. }\end{array}$ & 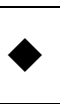 & & 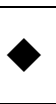 & $\begin{array}{l}V: \text { Accountability and } \\
\text { ethics }\end{array}$ \\
\hline 6. & $\begin{array}{l}\text { Evaluate the ethical and } \\
\text { professional issues arising from } \\
\text { the organization's use of network } \\
\text { information technology. }\end{array}$ & & & 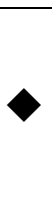 & $\begin{array}{l}V: \text { Ethics and } \\
\text { international and } \\
\text { domestic implications }\end{array}$ \\
\hline
\end{tabular}

*K $=$ knowledge, $\mathrm{S}=$ skills, $\mathrm{V}$ = values.

Table 2. Student learning outcomes associated with knowledge, skills, and values

Each competency has a specific scope; these can be defined as follows: 
Information literacy skills: The necessary tools that help students successfully navigate both the present and future landscape of information, and that "describe a set of abilities that enables an individual to acquire, evaluate, and use information" (Tong \& Moran, 2017).

- Communication skills: Students are encouraged to gain communication skills through writing, problem-solving, and case studies using graphics, multi-media methods, and pictorials. Additionally, students should understand how to organize reports, cite references, and upload their work to the e-learning site Moodle, which is the university's main form of communication. It is the student's responsibility to check the website daily for grade status, announcements, class materials, work submissions, etc. Moreover, students are encouraged to gain oral and listening skills through participating and communicating in case studies and assignments.

- Interpersonal skills: Students are encouraged to gain skills through projects and required group participation and discussion, as well as conflict resolution.

- $\quad$ Critical thinking: Students are encouraged to use critical thinking through problem-solving assignments and cases. This can be achieved by gathering and analyzing data, and using quantitative skills to solve a problem, case, or project. In addition, students will be encouraged to use innovation and creativity to solve problems or case studies.

- $\quad$ Ethics: Students are encouraged to solve ethical dilemmas (in-class ethical cases) by using "the six steps for resolving any ethical dilemma" (Arens et al., 2012).

- Accountability: Students are encouraged to practice accountability by meeting the deadlines for assignments, problems, case studies, and project submissions. Moreover, the quality of the students' work should be high, accurate, and professional.

- International and domestic implications: Students are encouraged to understand the international and domestic implications of the assignments and case studies given during the course. 


\subsection{Course Concepts and Content}

To determine the suitable suggested concepts covered in the course, a variety of related trends and innovations should be covered. Based on trends noted in the recent literature, and taking into consideration faculty responses gathered through the online survey, as well as the need to avoid teaching abstract theories to undergraduates without adding evidence of practice (Clayton \& Clopton, 2019; Qasim \& Kharbat, 2020), the development team proposed the following concepts for inclusion in the syllabus:

(1) Decision-making processes for accountants

(2) ERP, which will highlight the use of Excel, SAP, and SAGE

(2) Data analytics, RTI, and data mining

(3) Internet of things, Internet of everything, blockchain, and cloud computing

(4) Interactive features of Web $2.0 \&$ simple XBRL

(5) Information security and control frameworks

(6) Forensic accounting

\subsection{Course Assessment and Feedback}

It is known that assessment tools are an essential part of any syllabus to determine the achievement of students (Boud \& Falchikov, 2007). The effect of any assessment on students (also called "Washback") can be negative or positive based on the nature and style of the assessment (Benford, 2003). Because this syllabus combines learner-centered and competency-centered approaches, the course assessment should fit into one of these two styles. The assessment process outlined below is suggested as a comprehensive system that offers multiple opportunities and may be customized (Gervais, 2016) with multiple options so that students can decide which assignment to submit (Jones et al., 2016). Grades will be linked to related student learning objectives (SLOs) so that the student understands the overall assessment system. Some additional activities that give students extra points are also available, and penalties (e.g., for work submitted after the deadline or incomplete assignments) are removed, based on the recommendation of Jones et al. (2016). 
IFAC (2004, p.9) explained that case studies are a famous technique (method) for both teaching and assessing, especially in business courses, explaining that case study evaluation has three fundamental segments: the case study material, the understudies' planning dependent on that material and an appraisal (assessment) dependent on the case. Also, case study may likewise be utilized to evaluate group work, assessing such abilities as group working, introduction, examination and time-the board. Instructors, peers or facilitators will assess group work. The case technique for educating and assessing can give a ground-breaking motivation to understudies to learn theoretical concepts, empowering the use of theories to practice and the utilization of exact proof and information to help suggestions and ends. Significantly, using case study in the as assessment tool offers understudies the occasion to sightsee theoretical limitations.

Moreover, Daigle et al., (2007) used case study in the course AIS to explain how instructors uses case study to focus on skills based rather than content based competencies which included in the AICPA Core Competency Framework (2006) for the Accounting Information Systems course AIS learning potentials and then assessing student learning outcomes relative to these potentials and to obtain educational objectives. Aleqab et al. (2015) pointed out that classical assessment is not enough in covering the theoretical content rather than technical content; we need to enhance the traditional assessment to include the appropriate practical application and IT Knowledge according to (International Federation of Accountants (IFAC), 2010, p. 136). Following the leads from Aleqab et al. (2015), the below assessment tools are proposed.

Therefore, to have a complete picture, the distribution of grades across assessment tools is suggested and described as follows:

- Midterm examination (SLO 1, 2, 3, 6) $20 \%$

- Final examination (SLO 4, 5, 6) $20 \%$

- Course work $60 \%$

○ Only two assignments of four will be graded $30 \%$ :

- Assignment 1: Problem-solving (individual) (SLO 1,6) 15\%

- Assignment 2: Case analysis (individual) (SLO 2,6) $15 \%$

- Assignment 3: Case analysis (individual) (SLO 3,6) $\quad 15 \%$ 

- Assignment 4: Case analysis (individual) (SLO 4, 6)
$15 \%$
- Group project and presentation (group) (SLO 1, 2, 3, 6)
$15 \%$
○ Class discussion (individual) (SLO 5,6)
$15 \%$

- Extra bonus activity (individual research-based assignment) $10 \%$

\section{Course Work}

- $\quad$ Assignments: Case analysis (30\%)

Assignments 1, 2, 3, and 4 (individual assignments): Mini-cases and problemsolving. Two weeks prior to the due date, the mini-cases and problem-solving will be posted on Moodle, along with the questions. Only two assignments will be graded.

\section{- $\quad$ Group project presentation (15\%)}

Presentation: Group size should be three to four students. All members will be evaluated using a pre-defined rubric. Students can present their own perspectives on a topic that interests them during the course. The group is required to produce a 20-minute presentation for the class. They must use content from books, newspapers, or magazines. Unique examples should be presented, and other students' participation is required.

- $\quad$ Class discussion (15\%)

Students' attendance and participation are essential for this course. Students are expected to come to class on time and take an active role in class discussion and problem-solving.

\section{CONCLUSIONS AND FUTURE RESEARCH}

Syllabi design is a shared responsibility between professionals and universities through providing updated syllabi with up-to-date topics that are current in the workplace. The literature makes it clear that in order to help students adopt a deep learning approach, AIS courses must be outlined in a clear, approachable way through well-designed syllabi (Wessels, 2010).

This study is an important step on this road. It proposes the use of a newly developed AIS syllabus to meet the needs of the accounting profession for mastering new technological and intellectual challenges. AIS is a continuously 
evolving area that integrates accounting science with technology as a way to adapt to the current digital transformation. As we witness nowadays the pandemic of COVID-19 and the importance of technology in business and in the educational level, accounting programs worldwide have to adequately coordinate technology and the related information along with paying attention to integrate such abilities into the educational program, to create graduates that meet the current needs of organizations.

In this work, an investigation was conducted to explore the validity of the claim that AIS education is of low quality in the Middle East. A detailed investigation was conducted for 13 Arab countries in the Middle East to study the AIS syllabi status quo. As a result, it was found that AIS courses are offered by most Arab universities in the Middle East at a senior level. However, ease of access is considered as an indicator for quality of education. From this point of view, it was encountered through the investigation that information about these courses is not easy to find, or simply not available. Therefore, universities need to pay better attention to technology and to the content that is available on their websites.

The second fold of the research was to create a new, comprehensive syllabus for AIS course in the higher-education sector. Several types of syllabi development techniques were examined as the researchers worked to figure out which technique best suits AIS courses. A hybrid model was created based on learnercentered and competency-centered approaches. This model encourages the engagement of students and integrates assessment efforts and instructional delivery. The next step in this research comprised assembling the syllabus in terms of learning objectives, content, assessment tools, and feedback. Learning outcomes and content topics were identified based on the competencies outlined in the recent literature and responses collected from faculty in the field. Finally, assessment tools were created after taking into consideration the need to encourage and engage students and to focus on the needed competencies. As a result of developing syllabi for this AIS course, textbooks and material used to deliver the course were evaluated to match the syllabi learning outcomes. It is suggested that future research is done to test this Hybrid Syllabus application in the universities and expand the research to include other regions in the world and make a comparison between the studies. 
The AIS course is one of the important courses in the accounting curriculum and developing a Hybrid syllabus in the Era of Digitization, have many important practical implications related to students, educators and decision makers. As for accounting students, the implementation of the suggested syllabus will minimize the existing gap of AIS syllabus with the real-world requirements in the work placement, as modern accounting students are expected to have high level of IT knowledge and skills. For educators, institutional leaders and practitioners, the conclusion of this research can be used to guide the institutions toward a conscious awareness towards the importance of data availability from one side, and the importance of updating the tech-related courses from the other side. It is very critical that policy makers pay more attention for any lack of alignment between education and labour market, as the 21 Century demands better prepared workers for the labour force, "academia needs to be ready to meet this need" (Gervais, 2016).

In conclusion, developing a comprehensive syllabus in the higher-education sector will provide educators with a more cohesive syllabus that will serve stakeholders from universities to accounting communities.

\section{Limitations}

The first limitation of this research is that many universities are not represented in the study sample due to accessibility issues and lack of information on the websites. Also, the measurement of education quality in term of information delivered by universities website is not fully fulfilled and need to be addressed from different angles.

\section{REFERENCES}

AACSB. (2018). AACSB Business Accreditation Standards | Accounting Standards. Aacsb.Edu. https://www.aacsb.edu/accreditation/standards/accounting Accessed 16 December 2020.

Agrawal, A. K., \& Mittal, G. K. (2018). The role of ICT in higher education for the 21st century: ICT as a change agent for education. Multidisciplinary Higher Education, Research, Dynamics \& Concepts: Opportunities \& Challenges For Sustainable Development (ISBN 978-93-87662-12-4), 1(1), 76-83. http://conference.nrjp.co.in/index.php/MHERDC/article/view/16 Accessed 16 December 2020. 
AICPA. (2018). The AICPA Pre-certification Core Competency Framework. Thiswaytocpa.Com. https://www.aicpa.org/interestareas/accountingeducation/ resources/corecompetency.html Accessed 16 December 2020.

Al-eqab, M., Aleqab, A., \& Nasser, D. (2014). Accounting Information Systems Curriculum: Compliance with IFAC Requirements among Jordanian Universities. Vision 2020: Sustainable Growth, Economic Development, and Global Competitiveness.https://www.researchgate.net/publication/281029528_Mind the Gap_Accounting_Information_Systems_Curricula_Development_in_Compliance _With_IFAC_Standards_in_a_Developing_Country Accessed 16 December 2020.

Aleqab, M. M. A., Nurunnabi, M., \& Adel, D. (2015). Mind the Gap: Accounting Information Systems Curricula Development in Compliance With IFAC Standards in a Developing Country. Journal of Education for Business, 90(7), 349-358. https://doi.org/10.1080/08832323.2015.1068155

Apostolou, B., Dorminey, J. W., Hassell, J. M., \& Rebele, J. E. (2014). A summary and analysis of education research in accounting information systems (AIS). Journal of Accounting Education, 32(2), 99-112.

Arens, A. A., Elder, R. J., \& Mark, B. (2012). Auditing and assurance services: an integrated approach. Boston: Prentice Hall.

Arndt, H.-K., Isenmann, R., Brosowski, J., Thiessen, I., \& Gómez, J. M. (2006). Sustainability Reporting Using the eXtensible Business Reporting Language (XBRL). EnviroInfo, 75-82.

Azma, F. (2011). The Quality Indicators of Information Technology in Higher Education. Procedia - Social and Behavioral Sciences, 30, 2535-2537. https://doi.org/10.1016/j.sbspro.2011.10.494

Bakke, S., Faley, R. H., \& Steinberg, G. (2007). A student-centric approach to large introductory IS survey courses. Journal of Information Systems Education, 18(3), 321. https://search.proquest.com/docview/200167901 ?accountid=130846 Accessed 16 December 2020.

Belfo, F., \& Trigo, A. (2013). Accounting Information Systems: Tradition and Future Directions. Procedia Technology, 9, 536-546. https://doi.org/10.1016/j. protcy.2013.12.060

Bendovschi, A. C. (2015). The evolution of accounting information systems. SEA-Practical Application of Science, 3(07), 91-96. https://www.ceeol.com/search/ article-detail id=741373 Accessed 16 December 2020.

Bezpalko, O., Klishevych, N., Liakh, T., \& Pavliuk, R. (2016). Criteria and Indicators of University Education Quality: The Results of Expert Interview. The New Educational Review, 46(4), 61-71. https://doi.org/10.15804/tner.2016. 46.4.05 
Biggs, J. B. (1989). Approaches to the Enhancement of Tertiary Teaching. Higher Education Research \& Development, 8(1), 7-25. https://doi.org/10.1080/0729436 890080102

Book, P. A. (2014). All Hands on Deck: Ten Lessons from Early Adopters of Competency-Based Education. Western Interstate Commission for Higher Education. https://eric.ed.gov/?id=ed546830 Accessed 16 December 2020.

Boritz, J. E., \& Carnaghan, C. A. (2003). Competency-Based Education and Assessment for the Accounting Profession: A Critical Review*. Canadian Accounting Perspectives, 2(1), 7-42. https://doi.org/10.1506/5K7C-YT1H-0G3290K0

Boud, D., \& Falchikov, N. (2007). Rethinking assessment in higher education: Learning for the longer term. Routledge.

Bowe, A. G. (2015). The development of education indicators for measuring quality in the English-speaking Caribbean: How far have we come? Evaluation and Program Planning, 48, 31-46. https://doi.org/10.1016/j.evalprogplan. 2014.08.008

Bughin, J., Chui, M., \& Manyika, J. (2013). Ten IT-enabled business trends for the decade ahead. McKinsey Quarterly, 13(May).

CAA. (2019). Standards for Institutional Licensure and Program Accreditation Commission for Academic Accreditation - Ministry of Education -United Arab Emirates. Ministry of Education.

Cabaleiro-Cerviño, G., \& Vera, C. (2020). The Impact of Educational Technologies in Higher Education. GIST - Education and Learning Research Journal, 20, 155-169. https://doi.org/10.26817/16925777.711

Cabrol, M., \& Severin, E. (2010). ICT to improve quality in education-A conceptual framework and indicators in the use of information communication technology for education (ICT4E). Assessing the Effects of ICT in Education, 83.

Caglio, A. (2003). Enterprise Resource Planning systems and accountants: towards hybridization? European Accounting Review, 12(1), 123-153. https://doi.org/10.1080/0963818031000087853

Cearley, D. W., Burke, B., Searle, S., Walker, M. J., \& Claunch, C. (2017). The top 10 strategic technology trends for 2018. Gartner.

Chapman, D. W., \& Miric, S. L. (2009). Education Quality in the Middle East. International Review of Education, 55(4), 311-344. https://doi.org/10.1007/s 11159-009-9132-5 
Clayton, P. R., \& Clopton, J. (2019). Business curriculum redesign: Integrating data analytics. Journal of Education for Business, 94(1), 57-63. https://doi.org/10.1080/08832323.2018.1502142

Cullen, R., \& Harris, M. (2009). Assessing learner-centredness through course syllabi. Assessment \& Evaluation in Higher Education, 34(1), 115-125. https://doi.org/10.1080/02602930801956018

Daigle, R. J., Hayes, D. C., \& Hughes, K. E. (2007). Assessing Student Learning Outcomes in the Introductory Accounting Information Systems Course Using the AICPA's Core Competency Framework. Journal of Information Systems, 21(1), 149-169. https://doi.org/10.2308/jis.2007.21.1.149

Damasiotis, V., Trivellas, P., Santouridis, I., Nikolopoulos, S., \& Tsifora, E. (2015). IT Competences for Professional Accountants. A Review. Procedia Social and Behavioral Sciences, 175, 537-545. https://doi.org/10.1016/j. sbspro.2015.01.1234

Data.worldbank.org. (2019). World Bank. Data for Egypt, Arab Rep., Iraq, Saudi Arabia, Yemen, Rep., Syrian Arab Republic, Jordan, Lebanon, West Bank and Gaza, Oman, United Arab Emirates, Qatar, Kuwait, Bahrain. https://data.worldbank.org/?locations=EG-IQ-SA-YE-SY-JO-LB-PS-OM-AEQA-KW-BH Accessed 16 December 2020.

DiClementi, J. D., \& Handelsman, M. M. (2005). Empowering Students: ClassGenerated Course Rules. Teaching of Psychology, 32(1), 18-21. https://doi.org/10.1207/s15328023top3201_4

El Kadiri, S., Grabot, B., Thoben, K.-D., Hribernik, K., Emmanouilidis, C., von Cieminski, G., \& Kiritsis, D. (2016). Current trends on ICT technologies for enterprise information systems. Computers in Industry, 79, 14-33. https://doi.org/10.1016/j.compind.2015.06.008

Ellis, R. (2003). Designing a Task-Based Syllabus. RELC Journal, 34(1), 64-81. https://doi.org/10.1177/003368820303400105

Fink, L. D. (2013). Creating significant learning experiences: An integrated approach to designing college courses. John Wiley \& Sons.

Gervais, J. (2016). The operational definition of competency-based education. The Journal of Competency-Based Education, 1(2), 98-106. https://doi.org/ $10.1002 / \mathrm{cbe} 2.1011$

Gould, S. (2019). Building Data Science And Analytics Capabilities In Finance And Accounting. https://www.ifac.org/knowledge-gateway/preparing-futureready-professionals/discussion/building-data-science-and Accessed 16 December 2020 . 
Guragai, B., Hunt, N. C., Neri, M. P., \& Taylor, E. Z. (2017). Accounting Information Systems and Ethics Research: Review, Synthesis, and the Future. Journal of Information Systems, 31(2), 65-81. https://doi.org/10.2308/isys-51265

Handoyo, S., \& Anas, S. (2019). Accounting Education Challenges in the New Millennium Era: Impact of Advanced of Technology and Dynamic Business Environment. Journal of Accounting Auditing and Business, 2(1), 25. https:// doi.org/10.24198/jaab.v2i1.20429

Harrington, C., \& Thomas, M. (2018). Designing a motivational syllabus: Creating a learning path for student engagement. Stylus Publishing, LLC.

IFAC, International Federation of Accountants. (2007). Information Technology for Professional Accountants (I.E.P.S. 2).

IFAC, International Federation of Accountants. (2010). Handbook of international education pronouncements (2010 edition). https://www.ifac. org/system/files/publications/files/ies-4-professional-values.pdf Accessed 16 December 2020.

Ishiyama, J., Miller, W. J., \& Simon, E. (2015). Handbook on teaching and learning in political science and international relations. Edward Elgar Publishing. Islam, K., CH, A. R., Bilal, A. R., \& Ilyas, M. (2017). Accounting information systems: traditions and future directions (by using AIS in traditional organizations). The Journal of Internet Banking and Commerce, 22(2), 1-13. https://www.icommercecentral.com/open-access/accounting-information-systemstraditions-and-future-directions-by-using-ais-in-traditional-organizations.php?aid $=86088$ Accessed 16 December 2020 .

Johnstone, S. M., \& Soares, L. (2014). Principles for Developing CompetencyBased Education Programs. Change: The Magazine of Higher Learning, 46(2), 12-19. https://doi.org/10.1080/00091383.2014.896705

Jones, A., Olds, A., \& Lisciandro, J. (2016). Understanding the Learner: Effective course design in the changing higher education space. International Studies in Widening Participation, 3(1), 19-35. https://researchrepository.murdoch.edu.au /id/eprint/33016/1/understanding\%20the\%20learner.pdf Accessed 16 December 2020.

Akkary, R. (2014). Facing the challenges of educational reform in the Arab world. Journal of Educational Change, 15(2), 179-202. https://doi.org/10.1007/s10833013-9225-6

Kesswani, N., \& Kumar, S. (2016). Accessibility analysis of websites of educational institutions. Perspectives in Science, 8, 210-212. https://doi.org/10.1016/j.pisc.2016.04.031 
Krahel, J. P., \& Vasarhelyi, M. A. (2014). AIS as a Facilitator of Accounting Change: Technology, Practice, and Education. Journal of Information Systems, 28(2), 1-15. https://doi.org/10.2308/isys-10412

Krathwohl, D. R., \& Anderson, L. W. (2009). A taxonomy for learning, teaching, and assessing: A revision of Bloom's taxonomy of educational objectives. Longman.

Law, N., Niederhauser, D. S., Christensen, R., \& Shear, L. (2016). A multilevel system of quality technology-enhanced learning and teaching indicators. Educational Technology \& Society, 19(3), 72-83.

Le, C., Wolfe, R. E., \& Steinberg, A. (2014). The Past and the Promise: Today's Competency Education Movement. Students at the Center: Competency Education Research Series. Jobs For the Future.

Limijaya, A. (2018). An Overview of Accounting Ethics Course In Undergraduate Program Curriculum In Indonesia. AKRUAL: Jurnal Akuntansi, 9(2), 95. https://doi.org/10.26740/jaj.v9n2.p95-110

Liu, C., Yao, L. J., \& Hu, N. (2012). Improving Ethics Education in Accounting: Lessons from Medicine and Law. Issues in Accounting Education, 27(3), 671690. https://doi.org/10.2308/iace-50150

Lois, P., Tabouratzi, E., \& Makrygiannakis, G. (2017). Accounting Information Systems course: perceptions of accounting and non-accounting students. EuroMed Journal of Business, 12(3), 258-268. https://doi.org/10.1108/EMJB-11-2016-0032

Loo, I. De, \& Bots, J. (2018). The life of an accounting information systems research course. Accounting Education, 27(4), 358-382. https:// doi.org/10.1080/09639284.2018.1471726

Maali, B., \& Al-Attar, A. M. (2020). Accounting Curricula in Universities and Market Needs: The Jordanian Case. SAGE Open, 10(1), 215824401989946. https://doi.org/10.1177/2158244019899463

Mamaghani, H. J., \& Zolghadri, M. (2018). Issues in Syllabus Design. In Issues in Syllabus Design (pp. 69-80). Brill | Sense. https://doi.org/10.1163/ 9789463511889_006

Murphy, R. (2018). The Concept of Syllabus Design and Curriculum Development: A Look at Five Major Syllabus Designs. In Issues in Syllabus Design, 1-23. Brill Sense.

McPhail, K. (2001). The other objective of ethics education: Re-humanising the accounting profession--a study of ethics education in law, engineering, medicine and accountancy. Journal of Business Ethics, 34(3-4), 279-298. 
MoHE. (2018). Legislations of higher education. http://www.mohe.gov.jo/ar/ pages/Legislation.aspx Accessed 16 December 2020.

Monk, E., \& Wagner, B. (2012). Concepts in enterprise resource planning. Cengage Learning.

Noor-Ul-Amin, S. (2013). An effective use of ict for education and learning by drawing on worldwide knowledge, research, and experience. ICT as a Change Agent for Education. India: Department of Education, University of Kashmir, 113.

Palvia, S., Aeron, P., Gupta, P., Mahapatra, D., Parida, R., Rosner, R., \& Sindhi, S. (2018). Online Education: Worldwide Status, Challenges, Trends, and Implications. Journal of Global Information Technology Management, 21(4), 233-241. https://doi.org/10.1080/1097198X.2018.1542262

Parkes, J., \& Harris, M. B. (2002). The Purposes of a Syllabus. College Teaching, 50(2), 55-61. https://doi.org/10.1080/87567550209595875

Paterson, A. S., \& Wilson, M. J. (2018). The Routledge companion to accounting information systems, edited by Martin Quinn and Erik Strauss, published in 2018 by Routledge Taylor \&amp; Francis Group: London and New York. Accounting Forum, 42(3), 277-280. https://doi.org/10.1016/j.accfor.2018.06.001

Qasim, A., \& Kharbat, F. F. (2020). Blockchain Technology, Business Data Analytics, and Artificial Intelligence: Use in the Accounting Profession and Ideas for Inclusion into the Accounting Curriculum. Journal of Emerging Technologies in Accounting, 17(1), 107-117. https://doi.org/10.2308/jeta-52649

Qian, J., Ward, K., \& Blaskovich, J. (2012). Integrating IT Frameworks into the AIS Course. AIS Educator Journal, 7(1), 1-26. https://doi.org/10.3194/19358156-7.1.1

Quinn, M., \& Strauss, E. (2017). The Routledge Companion to Accounting Information Systems. Routledge.

Rezaee, Z., Ford, W., \& Elam, R. (2000). Real-time accounting systems. Internal Auditor, 57(2), 62.

Richmond, A. S. (2016). Constructing a Learner-Centered Syllabus: One Professor's Journey. IDEA Paper\# 60. IDEA Center, Inc.

Robb, M. (2012). The Learner-Centered Syllabus. The Journal of Continuing Education in Nursing, 43(11), 489-490. https://doi.org/10.3928/0022012420121024-26

Romney, M. B., \& Steinbart, P. J. (2018). Accounting Information Systems. Fourteenth. New York: Pearson. 
Rufino, H., Payabyab, R. G., \& Lim, G. T. (2017). Competency Requirements for Professional Accountants: Basis for Accounting Curriculum Enhancement. SSRN Electronic Journal. https://doi.org/10.2139/ssrn.3172508

Saichaie, K., \& Morphew, C. C. (2014). What College and University Websites Reveal about the Purposes of Higher Education. The Journal of Higher Education, 85(4), 499-530. https://doi.org/10.1080/00221546.2014.11777338

Scheckel, M. (2016). Designing courses and learning experiences. Teaching in Nursing: A Guide for Faculty, 159-185.

Scheer, A.-W., \& Habermann, F. (2000). Enterprise resource planning: making ERP a success. Communications of the ACM, 43(4), 57-61. https://doi.org/ $10.1145 / 332051.332073$

Sharifi, M., McCombs, G. B., Fraser, L. L., \& McCabe, R. K. (2009). Structuring a Competency-Based Accounting Communication Course At the Graduate Level. Business Communication Quarterly, 72(2), 177-199. https://doi.org/10. 1177/1080569909334052

Skordoulis, M., Sparangis, P., Stampolis, O., Mougkolia, I., Papageorgiou, A., \& Chondreli, C. (2015). A framework for quality in education: Applying quality function deployment to a higher education institute. 10th ERA International Scientific Conferences. Aigáleo, Greece.

Srdar, N. A. (2017). The gap between Learning and Teaching in Accounting Education: the Saudi Arabian Experience. University of Portsmouth.

Stoller, F. L. (2004). 12. CONTENT-BASED INSTRUCTION: PERSPECTIVES ON CURRICULUM PLANNING. Annual Review of Applied Linguistics, 24. https://doi.org/10.1017/S0267190504000108

Tempone, I., Kavanagh, M., Segal, N., Hancock, P., Howieson, B., \& Kent, J. (2012). Desirable generic attributes for accounting graduates into the twenty-first century. Accounting Research Journal, 25(1), 41-55. https://oi.org/ $10.1108 / 10309611211244519$

Tong, M., \& Moran, C. (2017). Are transfer students lagging behind in information literacy? Reference Services Review, 45(2), 286-297. https://doi.org/10.1108/RSR-10-2016-0064

Tran, H. M. T., \& Anvari, F. (2013). The Five-dimensional reflective cycle framework for designing financial information management systems courses. Electronic Journal of Information Systems Evaluation, 16(3), 242.

uniRank TM. (2019). uniRank. Main Page | uniRank ${ }^{T M}$. https://www.4icu.org/ 
Vial, G. (2019). Understanding digital transformation: A review and a research agenda. The Journal of Strategic Information Systems, 28(2), 118-144. https://doi.org/10.1016/j.jsis.2019.01.003

Weimer, M. (2002). Learner-centered teaching: Five key changes to practice. John Wiley \& Sons.

Wessels, P. L. (2010). A Critical Learning Outcome Approach in Designing, Delivering and Assessing the IT Knowledge Syllabus. Accounting Education, 19(5), 439-456. https://doi.org/10.1080/09639280903208534

Zhu, D., \& Li, G. (2019). Information Technology and Internal Controls: A Study of Chinese Commercial High-tech Enterprises. 2019 Chinese Control And Decision Conference (CCDC), 4271-4274. https://doi.org/10.1109/CCDC. 2019.8833174 


\section{Appendix A}

\section{Accounting Information Systems Course: Survey}

Dear Colleague,

We are working on designing a new syllabus for AIS. As a part of our study, we need you to fill the following questions. The questions will not take more than ten minutes in total. Thanks for taking this time, and thanks for helping us out.

\section{General Information}

1. University Name:

2. University Country:

3. University Type: $\square$ private $\square$ public(government) $\square$ semi public

4. Do you offer AIS (or related course)? $\square$ Yes $\square$ AIS is a major $\square$ No

If yes or AIS as a major,

\section{AIS Syllabi Details:}

5. The college that offers the course:

6. How many courses do you offer?

7. What are the name of courses offered related to AIS (please include AIS if it is a course by itself)

8. What is the prerequisite for the course:

9. Which year AIS is recommended: $\square$ Year $1 \square$ Year $2 \square$ Year $3 \square$ Year 4

\section{AIS Topics}

10. From your point of view, if you will suggest some topics for this course, choose what is appropriate (and add any other suggestion):

○ Enterprise resource planning (ERP)

○ Blockchain

○ Internet of Things

- Real Time Information

○ Extensible Business Reporting Language

- Decision-Making Process

○ SAP for Accounting

○ Forensic Accounting 
- Information Security \& Control Frameworks (COSO)

- Excel for Accounting

- Add any other suggested topic:

11. Comments: 